\title{
Contamination of Currency Notes with Kanamycin Resistant Shigella flexneri
}

Ebrahim Mohammed Al-Hajj ${ }_{5}^{*}$, Malik Suliman Mohamed ${ }^{2,3}$, Noha A. Abd Alfadil ${ }^{4}$, Hisham N. Altayb $^{5}$, Abeer Babiker Idris ${ }^{6}$, Salah-Eldin El-Zaki ${ }^{7}$ and Mohamed A. Hassan ${ }^{8,9}$

${ }^{1}$ Department of Pharmaceutical Chemistry, Faculty of Pharmacy, Omdurman Islamic University, Khartoum, Sudan

${ }^{2}$ Department of Pharmaceutics, College of Pharmacy, Jouf University, Sakaka, Kingdom of Saudi Arabia

${ }^{3}$ Department of Pharmaceutics, Faculty of Pharmacy, University of Khartoum, Khartoum, Sudan.

${ }^{4}$ Department of Pharmaceutical Microbiology, Faculty of Pharmacy, University of Alneelain, Khartoum, Sudan.

${ }^{5}$ Biochemistry department, College of sciences, King Abdulaziz University, Jeddah, Kingdom of Saudi Arabia.

${ }^{6}$ Department of Medical Microbiology, Faculty of Medical Laboratory Sciences, University of Khartoum, Khartoum, Sudan

${ }^{7}$ Department of Epidemiology, Molecular Epidemiology Laboratory, Tropical Medicine Research Institute, Khartoum, Sudan.

${ }^{8}$ Applied Bioinformatics Center, Africa City of Technology, Khartoum, Sudan.

${ }^{9}$ Department of Bioinformatics, DETAGEN Genetic Diagnostics Center, Kayseri, Turkey

*To whom correspondence should be addressed

Ebrahim Mohammed Al-Hajj

Department of Pharmaceutical Chemistry, Faculty of Pharmacy, Omdurman Islamic University, Khartoum, Sudan.Email: ebrahim.alhajj92@gmail.com 


\begin{abstract}
Shigella flexneri is the main causative agent of shigellosis commonly distributed in developing countries with high morbidity and mortality rates. This study aimed to examine the presence of Shigella species in Sudanese currency notes using both traditional and molecular techniques. One hundred thirty five currency notes were collected and their contaminants were isolated and identified conventionally and genetically using $16 \mathrm{~S}$ rRNA gene amplification and sequencing. Eight isolates were identified as Shigella species in different notes, and 3 of them were resistant to penicillin, kanamycin and nitrofurantoin. One $S$. flexneri isolate has insertion mutation of guanine nucleotide at position 730 of life's essential gene 16S rRNA which known evolutionarily to be stable gene. Banknotes are highly circulating items and therefore, appropriate measures such as regular replacement of the dirty notes with new papers are necessary to protect peoples from being infected with drug resistant pathogens.
\end{abstract}

Keywords: Shigella flexneri, 16S rRNA gene, currency notes, kanamycin, resistance.

\title{
1. Introduction
}

Shigella flexneri is a gram-negative, non-sporulated, non-motile and anaerobic facultative bacillus bacterium belongs to Enterobacteriaceae family (Penatti et al., 2007; Sun et al., 2013). Shigella species are common pathogenic bacteria which cause shigellosis that is characterized by acute bloody diarrhea (Sansonetti, 2001). The transmission of S. flexneri normally occur through fecal-oral route (Jennison and Verma, 2004) and its infections are limited to human only (Sansonetti, 2001; Gaurav et al., 2013). Annually, Shigella spp. causes 164.7 million infections over the world. In addition, children less than five years old are highly suffering from shigellosis and estimated to be $69 \%$ of all Shigellas' infections, while $61 \%$ of all deaths due to shigellosis occur in children (Kotloff et al.,1999). Shigella flexneri is the most frequent cause of shigellosis in developing countries with high morbidity and mortality rates (Kotloff et al.,1999; Vinh et al., 2009), and it was responsible for many outbreaks in the areas with crowding, poor sanitation and poor hygiene (Walden et al., 2005; Ranjbar et al., 2010; Shen et al., 2017). In 2004, an outbreak of shigellosis (1340 cases and 11 deaths) has been detected in North Darfur (Province located in the western of Sudan) (WHO, 2004). There is a variation in dominance of $S$. dysenteriae and $S$. flexneri in developing countries. Some studies conducted in Khartoum have reported that $S$. flexneri was the most common cause of shigellosis in Sudan (Saeed et al., 2015; Ahmed et al., 2000). Although shigellosis might be selflimited, but sever cases might be treated with various antibiotics such as ampicillin, co-trimoxazole and nalidixic acid. However, Shigella flexneri developed resistance to these drugs, therefore, WHO recommended ciprofloxacin as the drug of choice for treatment of shigellosis and ceftriaxone as an alternative treatment in the last decade (WHO, 2005), which also became ineffective in some cases. Shigella flexneri was identified by many methods including conventional microbial methods (Gaurav et al., 2013), identification of virulence plasmid with direct PCR assay (Mokhtari et al., 2012; Sansonetti et al., 1982) and 16S rRNA gene sequencing (Šimenc et al., 2008). The 16S rRNA gene, presents in almost all bacteria, is an essential gene for organisms survival (Yıldırım et al., 2011), and 
used in many studies for identification and classification of bacteria at strain level. The gene sequence, approximately $1500 \mathrm{bp}$, is suitable to contain phylogenetic information and its function is stable for long period of time (Patel, 2001; Janda and Abbott, 2007; Suardana, 2014). In fact, 16S rRNA gene was extensively used in taxonomy and identification of bacteria to species and strain levels (Gee et al., 2004; Woo et al., 2008), and also used to understand the resistance mechanisms of some bacteria to antibiotics (Springer et al., 2001). It is known that currency notes are widely used almost by all nations every day that subjected them to be contaminated by pathogenic microorganisms and transmission of these organisms between people (Gedik et al., 2013; Alemu, 2014; Osman et al., 2017). Shigella species might be one of these organisms that contaminate the currency notes. Therefore, this study was conducted to explore whether Shigella flexneri could be detected in Sudanese currency notes with the aid of 16S rRNA gene sequencing, which is more accurate and somewhat consuming less resources and time than conventional methods. In addition, in silico tools were used to understand the evolution of $S$. flexneri's $16 \mathrm{~S}$ rRNA gene circulating in Sudanese currency notes.

\section{Materials and Methods}

\subsection{Sample Collection}

A total of 135 Sudanese currency notes that randomly collected from hospitals, restaurants, public transportations and banks in Khartoum state were transferred into sterile plastic petri dishes to the laboratory of Pharmaceutical Microbiology in Omdurman Islamic University.

\subsection{Phenotypic Identification}

\subsubsection{Isolation and Identification of Shigella species}

Various microbiological techniques described previously (Cheesbrough, 2006) for bacterial identification were used to identify Shigella species. Both sides of currency notes that wetted with sterile distilled water were swabbed using cotton-tipped swab, inoculated on $5 \%$ blood agar plates and incubated aerobically at $37{ }^{\circ} \mathrm{C}$ for 24 hours. Separated colonies were sub-cultured in MacConkey agar, nutrient agar and xylose lysine desoxycholate agar plates. Biochemical tests: hydrogen sulfide, indole, motility, urease, voges proskauer, methyl red, citrate utilization, glucose fermenter, lactose fermenter, oxidase, catalase tests and gram staining techniques were carried out for preliminary identification of Shigella species.

\subsubsection{Antibiotic sensitivity Test}

Susceptibilities were investigated by disk diffusion method according to the protocol specified previously (Forbes et al., 2007), while inhibition zone diameters interpretations were carried out according to the European Committee on Antimicrobial Susceptibility Testing (EUCAST, 2016). Antibiotics used in this study were: amoxicillin $(25 \mu \mathrm{g})$, ampicillin $(30 \mu \mathrm{g})$, co-amoxyclav $(30 \mu \mathrm{g})$, cephalexin $(30 \mu \mathrm{g})$, cefuroxime $(30 \mu \mathrm{g})$, ceftriaxone $(30 \mu \mathrm{g})$, ceftazidime $(30 \mu \mathrm{g})$, gentamicin $(10 \mu \mathrm{g})$, kanamycin $(30 \mu \mathrm{g})$, co-trimoxazole $(25 \mu \mathrm{g})$, penicillin-G (10 IU), erythromycin $(5 \mu \mathrm{g})$, azithromycin $(15 \mu \mathrm{g})$, ciprofloxacin $(30 \mu \mathrm{g})$, levofloxacin $(5 \mu \mathrm{g})$, nitrofurantoin $(200 \mu \mathrm{g})$, vancomycin $(30 \mu \mathrm{g})$, chloramphenicol $(30 \mu \mathrm{g})$ and meropenem $(10 \mu \mathrm{g})$. 


\subsection{Molecular analysis}

$16 \mathrm{~S}$ rRNA gene analysis confirmatory test was carried out for the isolates identified as Shigella species and showed multiple drug resistance.

\subsubsection{DNA Extraction}

The bacterial genomic DNA was extracted using Chelex 100 method (Giraffa et al., 2000). Briefly, three colonies were transferred to a tube containing $200 \mu \mathrm{L}$ of $1 \mathrm{X}$ PBS, mixed by vortex for ten seconds using a vortex shaker (GEMMY industrial CORP, Taiwan), and centrifuged for five minutes. The supernatant was discarded and the pellet was suspended in $200 \mu \mathrm{L}$ of $6 \%$ Chelex reagent and incubated at $56{ }^{\circ} \mathrm{C}$ for fifteen to thirty minutes, and further boiled at $100{ }^{\circ} \mathrm{C}$ for fifteen minutes. After ten seconds vortexing and cooling at room temperature, the supernatant was collected with the aid of centrifugation.

\subsubsection{S rRNA gene amplification}

The 16S rRNA gene was amplified from genomic DNA by PCR using thermocycler (BIO-RAD, Mexico). Universal primers of 16S rRNA gene 27F (5'-AGAGTTTGATCCTGGCTCAG-3') and 1495R (5'- CTACGGCTACCTTGTTACGA-3') were used (Liu et al., 2009). The PCR was carried out using PreMix Mastermix kit (iNtRON Biotechnology) in $25 \mu \mathrm{L}$ reaction mixture containing 13 $\mu \mathrm{L}$ distill water, $1 \mu \mathrm{L}$ forward primer, $1 \mu \mathrm{L}$ reverse primer and $5 \mu \mathrm{L}$ DNA extract. The PCR consists of initial denaturation step at $94{ }^{\circ} \mathrm{C}$ for 5 min followed by 30 cycles of $\left[94{ }^{\circ} \mathrm{C}\right.$ for $1 \mathrm{~min}, 58{ }^{\circ} \mathrm{C}$ for 1 $\min$ and $72{ }^{\circ} \mathrm{C}$ for $2 \mathrm{~min}$ ], and final extension step at $72{ }^{\circ} \mathrm{C}$ for $10 \mathrm{~min}$ (Mokhtari et al., 2012). The PCR product was analyzed using $1 \%$ agarose gel electrophoresis (Lee et al., 2012) to check the presence of amplified fragment, $1500 \mathrm{bp}$, and sent to Macrogen Company in Netherlands for further purification and sequencing. The obtained sequence was deposited in the GenBank database under accession number KY199565 and the strain was named "ebra1".

\subsection{Bioinformatics Analysis}

The obtained sequence was manually cleaned by Finch TV software version 1.4.0 (Geospiza, Inc.; Seattle, WA, USA), and used to search the NCBI BLASTN program (Morgulis et al., 2008) for similar sequences. The obtained sequence was aligned with the top 15 similar sequences, that found to be of Shigella flexneri strains from different countries (Table 1) (Benson et al., 2005), using Unipro UGENE software version 1.25.0 (Okonechnikov et al., 2012). To study the evolutionary relationships between sequences, phylogenetic tree was constructed by MEGA software version 7 (Kumar et al., 2016) using Maximum Likelihood method of analysis (Tamura and Nei, 1993). 
Table 1: Shigella flexneri strains of other countries used in this study.

\begin{tabular}{|c|c|c|}
\hline Strain & Country & Accession number \\
\hline VITRNJ & India & JX307690.1 \\
\hline $1-1816 \mathrm{~S}$ & China & GU586143.1 \\
\hline am-BHI4 & Iran & KC017349.1 \\
\hline KNUC9043 & South Korea & JF505977.1 \\
\hline WAB1966 & Brazil & AM184304.1 \\
\hline ATCC 29903 & USA & NR_026331.1 \\
\hline MW-W 829 & Poland & KC835107.1 \\
\hline Tc2-1 & Japan & AB639118.1 \\
\hline OZK32 & Turkey & KT716263.1 \\
\hline LA3 & Pakistan & КT027776.1 \\
\hline Kilany_Ph & KSA & KU533727.1 \\
\hline B1.63 & South Africa & KU195384.1 \\
\hline 33 & UK & GU968178.1 \\
\hline CCB9F & Colombia & KU144700.1 \\
\hline 2P1C4 & Spain & HF936932.1 \\
\hline
\end{tabular}




\section{Results}

\subsection{Isolation and Identification}

Eight selected gram negative isolates from different banknotes (5.93\% from 135 notes) were identified as Shigella species using biochemical tests (Table 2).

Table 2: Biochemical test results for 8 isolated colonies.

\begin{tabular}{|c|c|c|c|c|c|c|c|c|c|c|c|}
\hline Test & $\mathbf{H}_{2} \mathbf{S}^{\mathbf{a}}$ & Indole & Motility & $\begin{array}{c}\text { Urease } \\
\text { test }\end{array}$ & $\begin{array}{c}\text { Citrate } \\
\text { utilization }\end{array}$ & $\mathbf{V P}^{\mathbf{b}}$ & $\mathbf{M R}^{\mathrm{c}}$ & $\begin{array}{c}\text { Lactose } \\
\text { fermenter }\end{array}$ & $\begin{array}{l}\text { Glucose } \\
\text { fermenter }\end{array}$ & $\begin{array}{c}\text { Catalase } \\
\text { test }\end{array}$ & $\begin{array}{c}\text { Oxidase } \\
\text { test }\end{array}$ \\
\hline Result & - & - & - & - & - & - & + & - & - & + & - \\
\hline
\end{tabular}

${ }^{\mathrm{a}}\left(\mathrm{H}_{2} \mathrm{~S}\right)$ : Hydrogen Sulfide; ${ }^{\mathrm{b}}$ (VP): Voges Proskauer; ${ }^{\mathrm{c}}$ (MR): Methyl Red. 


\subsection{Sensitivity Test}

The first Shigella isolate was found to be resistant to penicillins (amoxicillin, ampicillin, coamoxyclav and penicillin-G), kanamycin and nitrofurantoin, while the second isolate was found to be resistant to tested penicillins, but not co-amoxyclav. The remaining 6 isolates were found to be sensitive to all antibiotics tested (Table 3 ).

Table 3: Shigella isolates sensitivities.

\begin{tabular}{|c|c|c|c|c|c|c|c|c|c|c|c|c|c|c|c|c|c|c|c|}
\hline \multirow{2}{*}{$\begin{array}{c}\text { Isolat } \\
\text { e }\end{array}$} & \multicolumn{19}{|c|}{ Antibiotics } \\
\hline & AMX & AMC & AMP & $\mathbf{P}$ & $\mathrm{CN}$ & CXM & CTR & CAZ & MEM & VA & GEN & $\mathbf{K}$ & $\mathbf{E}$ & AZM & C & CIP & LE & COT & NIT \\
\hline & a & b & c & d & e & f & $\mathrm{g}$ & h & $\mathrm{i}$ & $\mathbf{j}$ & k & 1 & $\mathrm{~m}$ & n & o & p & q & $\mathrm{r}$ & s \\
\hline 1 & $\mathbf{R}^{\mathbf{t}}$ & $\mathbf{R}$ & $\mathbf{R}$ & $\mathbf{R}$ & $\mathbf{S}$ & $\mathbf{S}$ & $\mathbf{I}^{\mathbf{v}}$ & $\mathbf{S}$ & $\mathbf{S}$ & I & $\mathbf{S}$ & $\mathbf{R}$ & I & $\mathbf{S}$ & $\mathbf{S}$ & $\mathbf{S}$ & $\mathbf{S}$ & $\mathbf{S}$ & $\mathbf{R}$ \\
\hline 2 & $\mathbf{R}$ & $\mathbf{S}$ & $\mathbf{R}$ & $\mathbf{R}$ & $\mathbf{S}$ & $\mathbf{S}$ & $\mathbf{S}$ & $\mathbf{S}$ & $\mathbf{S}$ & $\mathbf{S}$ & $\mathbf{S}$ & $\mathbf{S}$ & $\mathbf{S}$ & $\mathbf{S}$ & $\mathbf{S}$ & $\mathbf{S}$ & $\mathbf{S}$ & $\mathbf{S}$ & $\mathbf{S}$ \\
\hline 3 & $\mathbf{S}^{\mathrm{u}}$ & $\mathbf{S}$ & $\mathbf{S}$ & $\mathrm{S}$ & $\mathbf{S}$ & $\mathbf{S}$ & $\mathbf{S}$ & $\mathbf{S}$ & $\mathbf{S}$ & $\mathbf{S}$ & $\mathbf{S}$ & $\mathbf{S}$ & $\mathbf{S}$ & $\mathbf{S}$ & $\mathbf{S}$ & $\mathbf{S}$ & $\mathbf{S}$ & $\mathbf{S}$ & $\mathbf{S}$ \\
\hline 4 & $\mathbf{S}$ & $\mathbf{S}$ & $\mathbf{S}$ & $\mathrm{S}$ & $\mathbf{S}$ & $\mathbf{S}$ & $\mathbf{S}$ & $\mathbf{S}$ & $\mathbf{S}$ & $\mathbf{S}$ & $\mathbf{S}$ & $\mathbf{S}$ & $\mathbf{S}$ & $\mathbf{S}$ & $\mathbf{S}$ & $\mathbf{S}$ & $\mathbf{S}$ & $\mathbf{S}$ & $\mathbf{S}$ \\
\hline 5 & $\mathbf{S}$ & $\mathbf{S}$ & $\mathbf{S}$ & $\mathrm{S}$ & $\mathbf{S}$ & $\mathbf{S}$ & $\mathbf{S}$ & $\mathbf{S}$ & $\mathbf{S}$ & $\mathbf{S}$ & $\mathbf{S}$ & $\mathbf{S}$ & $\mathbf{S}$ & $\mathbf{S}$ & $\mathbf{S}$ & $\mathbf{S}$ & $\mathbf{S}$ & $\mathbf{S}$ & $\mathbf{S}$ \\
\hline 6 & $\mathbf{S}$ & $\mathbf{S}$ & $\mathbf{S}$ & $\mathrm{S}$ & $\mathbf{S}$ & $\mathbf{S}$ & $\mathbf{S}$ & $\mathbf{S}$ & $\mathbf{S}$ & $\mathbf{S}$ & $\mathbf{S}$ & $\mathbf{S}$ & $\mathbf{S}$ & $\mathbf{S}$ & $\mathbf{S}$ & $\mathbf{S}$ & $\mathbf{S}$ & $\mathbf{S}$ & $\mathbf{S}$ \\
\hline 7 & $\mathbf{S}$ & $\mathbf{S}$ & $\mathbf{S}$ & $\mathrm{S}$ & $\mathbf{S}$ & $\mathbf{S}$ & $\mathbf{S}$ & $\mathbf{S}$ & $\mathbf{S}$ & $\mathbf{S}$ & $\mathbf{S}$ & $\mathbf{S}$ & $\mathbf{S}$ & $\mathbf{S}$ & $\mathbf{S}$ & $\mathbf{S}$ & $\mathbf{S}$ & $\mathbf{S}$ & $\mathbf{S}$ \\
\hline 8 & $\mathbf{S}$ & $\mathbf{S}$ & $\mathbf{S}$ & $\mathrm{S}$ & $\mathbf{S}$ & $\mathbf{S}$ & $\mathbf{S}$ & $\mathbf{S}$ & $\mathbf{S}$ & $\mathbf{S}$ & $\mathbf{S}$ & $\mathbf{S}$ & $\mathbf{S}$ & $\mathbf{S}$ & $\mathbf{S}$ & $\mathbf{S}$ & $\mathbf{S}$ & $\mathbf{S}$ & $\mathbf{S}$ \\
\hline
\end{tabular}

a (AMX): amoxicillin; ${ }^{\mathrm{b}}(\mathrm{AMC})$ : co-amoxyclav; ${ }^{\mathrm{c}}(\mathrm{AMP})$ : ampicillin; ${ }^{\mathrm{d}}(\mathrm{P})$ : penicillin-G; ${ }^{\mathrm{e}}(\mathrm{CN})$ : cephalexin; ${ }^{\mathrm{f}}(\mathrm{CXM})$ :

cefuroxime; ${ }^{\mathrm{g}}(\mathrm{CTR})$ : ceftriaxone; ${ }^{\mathrm{h}}(\mathrm{CAZ})$ : ceftazidime; ${ }^{\mathrm{i}}(\mathrm{MEM})$ : meropenem; ${ }^{\mathrm{j}}(\mathrm{VA})$ : vancomycin; ${ }^{\mathrm{k}}(\mathrm{GEN})$ : gentamicin;

${ }^{l}(\mathrm{~K})$ : kanamycin; ${ }^{\mathrm{m}}(\mathrm{E})$ : erythromycin; ${ }^{\mathrm{n}}(\mathrm{AZM})$ : azithromycin; ${ }^{\mathrm{o}}(\mathrm{C})$ : chloramphenicol; ${ }^{\mathrm{P}}(\mathrm{CIP})$ : ciprofloxacin; ${ }^{\mathrm{q}}(\mathrm{LE})$ :

levofloxacin; ${ }^{\mathrm{r}}(\mathrm{COT})$ : co-trimoxazole; ${ }^{\mathrm{s}}(\mathrm{NIT})$ : nitrofurantoin; ${ }^{\mathrm{t}}(\mathrm{R})$ : resistance; ${ }^{\mathrm{u}}(\mathrm{S})$ : sensitive; ${ }^{\mathrm{v}}(\mathrm{I})$ : Intermediate.

\subsection{Bioinformatics Analysis}

The 16S rRNA gene sequence of our sample ebral, after cleaning (702 base pairs), was found to be 100\% identical to Shigella flexneri (strain VITRNJ, India: JX307690.1) based on BLASTN search output. Their alignment to other related sequences including the reference (strain ATCC 29903, USA: NR_026331.1) showed that there is a guanine nucleotide insertion at position 730 (Figure 1.C), and also, they are clustered together in the same phylogenetic tree sub-branch, (Figure 1.D). 


\section{Discussion}

16S rRNA gene sequencing has become one of the most preferred technique for identification of bacteria that it might give information to species and strain level. We identified Shigella spp. in banknotes by phenotypic method and confirmed it as $S$. flexneri using $16 \mathrm{~S}$ rRNA gene sequencing. There are some difficulties facing researchers identifying bacteria by phenotypic approaches such as the length of the tests and variations of strains in the same species. Many authors prefer partial 16S rRNA gene sequencing method (Šimenc et al., 2008) for bacterial identification, which gives more accurate, reproducible and robust results (Clarridge, 2004). Shigella is one of the organisms that should not contaminate our daily contact objects such as banknotes, due to the fact that it causes more severe disease with greater morbidity (Navia et al., 2005). It is a highly contagious organism with infective dose of only 10-100 viable cells and an incubation period of 1-5 days. Better community hygiene practices could help in reducing the chance of Shigella diseases, which transmitted mainly to fomites with contaminated hands and other interpersonal contacts (Ko et al., 2013; Li et al., 2016). Although Shigella is a fragile and remains viable for a limited time outside human body (Sack et al., 2001), but we detected Shigella spp. in 5.93\% of the tested Sudanese currency notes, that might be a potential source of infection. It seems that countries borders do not prevent the transmission of social cultures between nations, this could be reflected partially by this finding and the presence of Shigella in Pakistani currency notes (6\% from 167) (Ali et al., 2015), possibly, the organism from feces transferred to hands and then to currency. There is a possibility that the rate of Shigella contamination is even higher than what we found, and using cultureindependent approaches for identification may increase the rate. But the identification of drug resistance patterns would not be possible using these approaches (Jalali et al., 2015).

Multiple sequence alignment of ebral with the other similar sequences retrieved from GenBank database shows insertion mutation of guanine nucleotide in ebral and JX307690.1 genes in position 730. Actually these 2 genes bearing 100\% similar sequences (Figure 1.C), and they are clustered together in the same phylogenetic tree sub-branch (Figure 1.D). While GU586143.1 gene of China strain is exactly similar to these two genes without this insertion mutation; consequently, they were clustered together in the same phylogenetic tree branch. It is not clear that whether this mutation is implicated in drug resistance or not, however, the $S$. flexneri isolate showed resistance to different antibiotics including penicillins (amoxicillin, ampicillin, co-amoxyclav and penicillin-G), kanamycin and nitrofurantoin. Likewise, S. flexneri isolated from different samples worldwide such as Sudan (Ahmed et al., 2000), India (Hosseini et al., 2010; Bhattacharya et al., 2014), China, (Pan et al., 2006; Pu et al., 2009), Taiwan (Ko et al., 2013), Nepal (Parajuli et al., 2017), Malaysia (Koh et al., 2012), Missouri, USA (Arvelo et al., 2009), New Zealand (Upton et al., 2007), Australia (Stafford et al., 2007) and Yemen (Al-Moyed et al., 2006) were resistant to several antibiotics, even those commonly used for their treatment. The exact reasons behind spread of resistance might not be fully clear, however, socioeconomic and behavioral factors (Okeke et al., 1999), and travelling (Navia et al., 2005) might result in increasing the spread of multi-drug resistant microorganisms. The molecular bases for drug resistance in Shigella spp. has been extensively studied and part of these studies with the impact of chromosomal mutations shown in (Table 4). 
Table 4: S. flexneri chromosomal mutations and their resulting phenotypes.

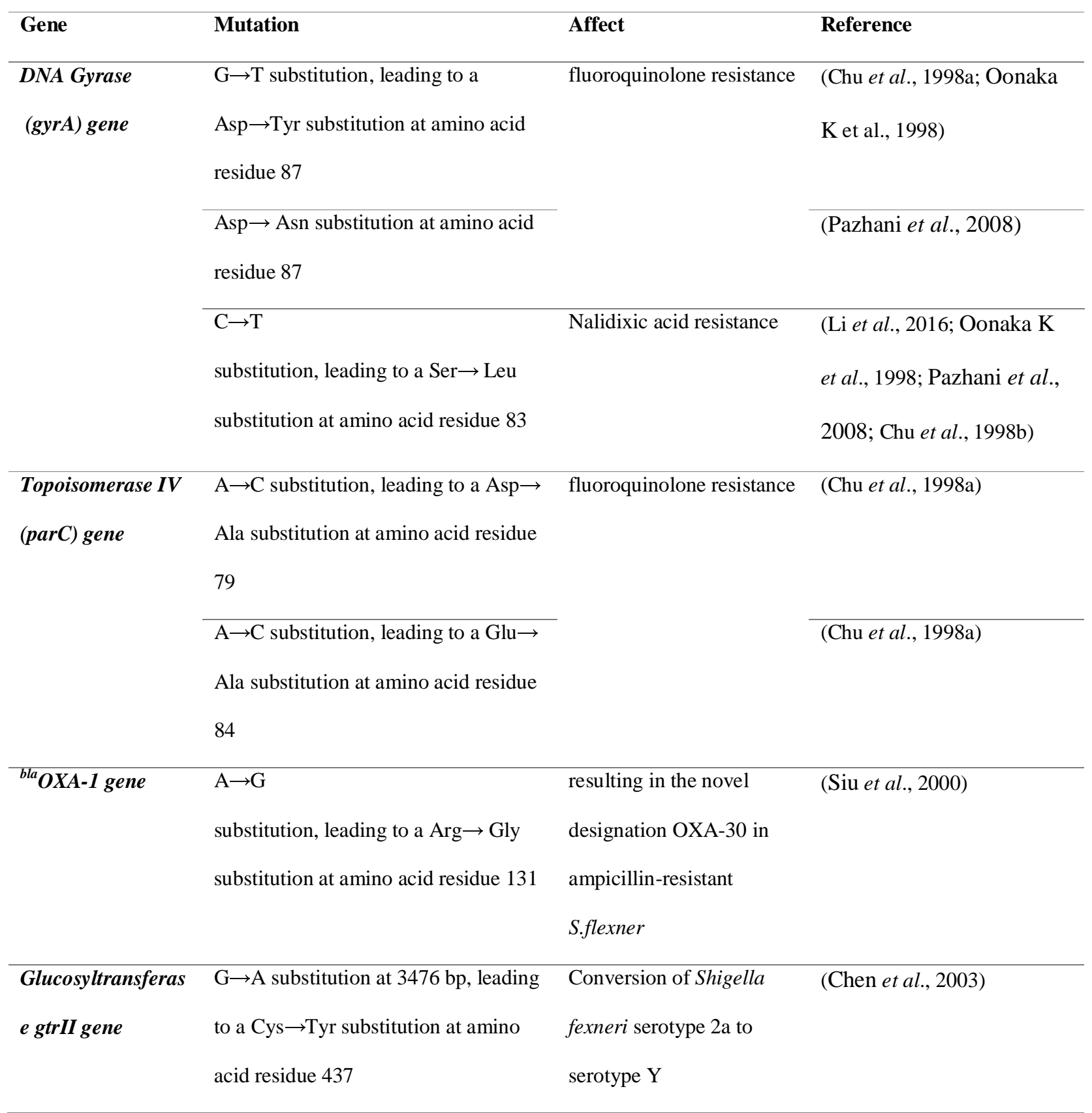


On the other hand, mutations in 16S rRNA gene is not without value, they might result in resistance to protein synthesis inhibitors especially those bind to the $30 \mathrm{~S}$ subunit of microbial ribosomes as illustrated by Moazed and Noller (Moazed and Noller, 1987), and several other studies shown in (Table 5).

Table 5: Mutations in 16S rRNA gene that documented by several species and strains.

\begin{tabular}{|c|c|c|}
\hline Mutation & Affect & Reference \\
\hline G360A & tetracycline resistance & (Trieber and Taylor 2002) \\
\hline triple mutation, AGA $_{965}{ }^{-967}$ TTC & & $\begin{array}{l}\text { (Trieber and Taylor 2002; Gerrit } \\
\text { et al., 2003) }\end{array}$ \\
\hline deletion of G942 & & (Trieber and Taylor 2002) \\
\hline deletion of G771 & & (Trieber and Taylor 2002) \\
\hline G1058C mutation & Drug resistance in Propionibacterium acnes & (Ross et al., 1998) \\
\hline Insertion of C530 & Streptomycin resistance and dependence & (Honore et al., 1995) \\
\hline $\begin{array}{l}\text { C512, A513, and C516 are } \\
\text { substituted by other bases }\end{array}$ & Streptomycin resistance & (Honore et al., 1995) \\
\hline A1400G, C1401T, G1483T & kanamycin resistance & (Suzuki et al., 1998) \\
\hline A1408G & $\begin{array}{l}\text { amikacin, kanamycin and gentamicin } \\
\text { resistance }\end{array}$ & $\begin{array}{l}\text { (Nessar et al., 2001; Prammananan } \\
\text { et al., 1998; Recht et al., 1999) }\end{array}$ \\
\hline T1406A, C1409T, G1491T, & kanamycin resistance and reduction of other & (Nessar et al., 2001; Prammananan \\
\hline G1449C & aminoglycosides binding affinity & et al., 1998; Recht et al., 1999) \\
\hline
\end{tabular}

It is known that there are various mechanisms behind aminoglycosides resistance, however, resistance of $S$. flexneri to kanamycin detected in this study might be attributed to the insertion mutation of guanine in 16S rRNA gene that might need further studies to be confirmed. There is no doubt that drug resistance might exaggerate the threat of shigellosis especially in developing countries where shigellosis is endemic (Sack et al., 2001).

The presence of multi-drug resistant microorganisms in highly circulating items such as currency notes will be of significant health implications. Improving personal hygiene and raising the public awareness might tackle the spreading of these microbes. 


\section{Conclusions}

We have detected a multi-drug resistant strain of $S$. flexneri in currency notes circulating in Sudan using conventional methods of identification and 16S rRNA gene sequencing. The identified insertion mutation, G730 in 16S rRNA gene, does not affect ribosome function and the organism was viable in the tested currency notes. However, it might be a mechanism behind kanamycin resistance that detected in this study, possibly, by shifting the nucleotides of the decoding A site (aminoglycoside binding site) since they are downstream to the insertion mutation site. Regular investigations of the presence of infectious agents in currency notes, replacement of the dirty and/or old currency with new ones combined with improving personal hygiene are necessary to avoid pathogenic microbial transmission through currency notes.

\section{Conflicts of interest}

The authors declare that there is no conflict of interest. 


\section{References}

Ahmed AA, Osman H, Mansour AM, Musa HA, Ahmed AB, Karrar Z, and Hassan HS. 2000. Antimicrobial agent resistance in bacterial isolates from patients with diarrhea and urinary tract infection in the Sudan. Am J Trop Med Hyg. 63:259-63.

Alemu A. 2014. Microbial contamination of currency notes and coins in circulation: A potential public health hazard. Biomedicine and Biotechnology. 2:46-53.

Ali R, Abbas SZ, Hussain Z, Hussain K, Hayat A, and Khan A. 2015. Bacteriological Analysis and Antibiogram of Pakistani Paper Currency Notes in Circulation in Karachi, Sindh, Pakistan. International Journal of Scientific Research in Environmental Sciences. 3:370-376.

Al-Moyed KA, Harmal NS, Al-Harasy AH, and Al-Shamahy HA. 2006. Increasing single and multiantibiotic resistance in Shigella species isolated from shigellosis patients in Sana'a, Yemen. Saudi Med J. 27:1157-60.

Arvelo W, Hinkle CJ, Nguyen TA, Weiser T, Steinmuller N, Khan F, Gladbach S, Parsons M, Jennings D, Zhu BP, Mintz E, and Bowen A. 2009. Transmission risk factors and treatment of pediatric shigellosis during a large daycare center-associated outbreak of multidrug resistant Shigella sonnei: implications for the management of shigellosis outbreaks among children. Pediatr Infect Dis J. 28: $976-80$

Benson DA, Karsch-Mizrachi I, Lipman DJ, Ostell J, and Wheeler DL. 2005. GenBank. Nucleic Acids Res. 33:D34-D38.

Bhattacharya D, Bhattacharya H, Thamizhmani R, Sayi DS, Reesu R, Anwesh M, Kartick C, Bharadwaj AP, Singhania M, Sugunan AP, and Roy S. 2014. Shigellosis in Bay of Bengal Islands, India: clinical and seasonal patterns, surveillance of antibiotic susceptibility patterns, and molecular characterization of multidrug-resistant Shigella strains isolated during a 6-year period from 2006 to 2011. Eur J Clin Microbiol Infect Dis. 33:157-70.

Cheesbrough M. 2006. District laboratory practice in tropical countries, 2nd ed. vol. 2: Cambridge University Press. The Edinburgh Building, Cambridge CB2 8RU, UK.

Clarridge JE. 2004. Impact of 16S rRNA gene sequence analysis for identification of bacteria on clinical microbiology and infectious diseases. Clin Microbiol Rev. 17:840-62.

Chen JH, Hsu WB, Chiou CS, and Chen CM. 2003. Conversion of Shigella flexneri serotype 2a to serotype $\mathrm{Y}$ in a shigellosis patient due to a single amino acid substitution in the protein product of the bacterial glucosyltransferase gtrII gene. FEMS Microbiol Lett. 224:277-83. 
Chu YW, Houang ET, and Cheng AF.1998a. Novel combination of mutations in the DNA gyrase and topoisomerase IV genes in laboratory-grown fluoroquinolone-resistant Shigella flexneri mutants. Antimicrob Agents Chemother. 42:3051-2.

Chu YW, Houang ET, Lyon DJ, Ling JM, Ng TK, and Cheng AF. 1998b. Antimicrobial resistance in Shigella flexneri and Shigella sonnei in Hong Kong, 1986 to 1995. Antimicrob Agents Chemother. 42:440-3.

EUCAST. (2016). The European Committee on Antimicrobial Susceptibility Testing. http://www.eucast.org (Last Accessed February 2019).

Forbes BA, Sahm DF, and Weissfeld AS. 2007. Bailey \& Scott's Diagnostic Microbiology,12 Edition, Mosby, United States.

Gaurav A, Singh SP, Gill JPS, Kumar R, and Kumar D. 2013. Isolation and identification of Shigella spp. from human fecal samples collected from Pantnagar, India. Vet World. 6:376-379.

Gedik H, Voss TA, and Voss A. 2013. Money and transmission of bacteria. Antimicrob Resist Infect Control. 2:22.

Gee JE, De BK, Levett PN, Whitney AM, Novak RT, and Popovic T. 2004. Use of 16S rRNA gene sequencing for rapid confirmatory identification of Brucella isolates. J Clin Microbiol. 42:3649-54.

Gerrits MM, Berning M, Van Vliet AH, Kuipers EJ, and Kusters JG. 2003. Effects of 16S rRNA gene mutations on tetracycline resistance in Helicobacter pylori. Antimicrob Agents Chemother. 47:2984-6.

Giraffa G, Rossetti L, Neviani E. 2000. An evaluation of chelex-based DNA purification protocols for the typing of lactic acid bacteria. J Microbiol Methods. 42:175-84.

Honore N, Marchal G, and Cole ST. 1995. Novel mutation in 16S rRNA associated with streptomycin dependence in Mycobacterium tuberculosis. Antimicrob Agents Chemother. 39:769-70.

Hosseini A, Dutta S, Nandy S, Ghosh I, and Khandekar P. 2012. Characterization of Shigella flexneri Isolates by Tandem Repeat Analysis and Pulsed-Field Gel Electrophoresis. $3^{\text {rd }}$ International Conference on Biology, Environment and Chemistry 46(2012). IACSIT Press, Singapore.

Jalali S, Kohli S, Latka C, Bhatia S, Vellarikal SK, Sivasubbu S, Scaria V, and Ramachandran S. 2015. Screening currency notes for microbial pathogens and antibiotic resistance genes using a shotgun metagenomic approach. PLoS One. 10:e0128711.

Janda JM, and Abbott SL, 2007. 16S rRNA gene sequencing for bacterial identification in the diagnostic laboratory: pluses, perils, and pitfalls. J Clin Microbiol. 45:2761-4. 
Jennison AV, and Verma NK. 2004. Shigella flexneri infection: pathogenesis and vaccine development. FEMS Microbiol Rev. 28:43-58.

Ko CF, Lin NT, Chiou CS, Wang LY, Liu MC, Yang CY., and Lee YS. 2013. Infrequent crosstransmission of Shigella flexneri 2a strains among villages of a mountainous township in Taiwan with endemic shigellosis. BMC Infect Dis. 13:354.

Koh XP, Chiou CS, Ajam N, Watanabe H, Ahmad N, and Thong KL. 2012. Characterization of Shigella sonnei in Malaysia, an increasingly prevalent etiologic agent of local shigellosis cases. BMC Infect Dis. 12:122.

Kotloff KL, Winickoff JP, Ivanoff B, Clemens JD, Swerdlow DL, Sansonetti PJ, Adak GK, and Levine MM. 1999. Global burden of Shigella infections: implications for vaccine development and implementation of control strategies. Bull World Health Organ. 77:651-66.

Kumar S, Stecher G, and Tamura K. 2016. MEGA7: Molecular Evolutionary Genetics Analysis version 7.0 for bigger datasets. Mol Biol Evol. 33:1870-4.

Lee PY, Costumbrado J, Hsu CY, and Kim YH. 2012. Agarose gel electrophoresis for the separation of DNA fragments. $J$ Vis Exp. 20:3923.

Liu W, Sun Z, Zhang J, Gao W, Wang W, Wu L, Sun T, Chen W, Liu X, and Zhang H. 2009. Analysis of microbial composition in acid whey for dairy fan making in Yunnan by conventional method and 16S rRNA sequencing. Curr Microbiol. 59:199-205.

Li S, Wang J, Wei X, Liu Y, You L, Luo X, Tang G, Sun Q, Ye C, Xu J, and Wang D. 2016. Molecular Characterization of Shigella sonnei: An Increasingly Prevalent Etiologic Agent of Shigellosis in Guizhou Province, Southwest of China. PLoS One. 11:e0156020.

Moazed D, and Noller HF. 1987. Interaction of antibiotics with functional sites in 16S ribosomal RNA. Nature. 327:389-94.

Mokhtari W, Nsaibia S, Majouri D, Ben Hassen A, Gharbi A, and Aouni M. 2012. Detection and characterization of Shigella species isolated from food and human stool samples in Nabeul, Tunisia, by molecular methods and culture techniques. J Appl Microbiol. 113:209-22.

Morgulis A, Coulouris G, Raytselis Y, Madden TL, Agarwala R, and Schäffer AA. 2008. Database indexing for production MegaBLAST searches. Bioinformatics. 24:1757-64.

Navia MM, Gascón J, and Vila J. 2005. Analysis of the mechanisms of resistance to several antimicrobial agents in Shigella spp. causing travellers' diarrhoea. Clin Microbiol Infect. 11:1044-7. 
Nessar R, Reyrat JM, Murray A, and Gicquel B. 2011. Genetic analysis of new 16S rRNA mutations conferring aminoglycoside resistance in Mycobacterium abscessus. J Antimicrob Chemother. 66:1719-24.

Okeke IN, Lamikanra A, and Edelman R. 1999. Socioeconomic and behavioral factors leading to acquired bacterial resistance to antibiotics in developing countries. Emerg Infect Dis. 5:18-27.

Okonechnikov K, Golosova O, Fursov M, and UGENE team. 2012. Unipro UGENE: a unified bioinformatics toolkit. Bioinformatics. 28:1166-1167.

Oonaka K, Fukuyama M, Tanaka M, Sato K, Ohnishi K, Ajima I, and Murata M. 1998. Mechanism of resistance of Shigella flexneri 2a resistant to new quinolone antibiotics. Kansenshogaku Zasshi. 72:365-70.

Osman AM, Hashim SO, Musa MA, and Tahir OM. 2017. Aerobic Bacteriological Contamination of Sudanese Currency in Port Sudan, Sudan. International Journal of Chinese Medicine. 1:132-136

Pan JC, Ye R, Meng DM, Zhang W, Wang HQ, and Liu KZ. 2006. Molecular characteristics of class 1 and class 2 integrons and their relationships to antibiotic resistance in clinical isolates of Shigella sonnei and Shigella flexneri. J Antimicrob Chemother. 58:288-96.

Parajuli NP, Joshi G, Pardhe BD, Shakya J, Bhetwal A, Shakya S, Pandit R, Shrestha SS, and Khanal PR. 2017. Shigellosis Caused by CTX-M Type ESBL Producing Shigella flexneri in Two Siblings of Rural Nepal: First Case Report from the Country. Case Rep Infect Dis. 2017:1862320.

Prammananan T, Sander P, Brown BA, Frischkorn K, Onyi GO, Zhang Y, Böttger EC, and Wallace RJ Jr. 1998. A single 16S ribosomal RNA substitution is responsible for resistance to amikacin and other 2-deoxystreptamine aminoglycosides in Mycobacterium abscessus and Mycobacterium chelonae. J Infect Dis. 177:1573-81.

Patel JB. 2001. 16S rRNA Gene Sequencing for Bacterial Pathogen Identification in the Clinical Laboratory. Mol Diagn. 6:313-21.

Pazhani GP, Niyogi SK, Singh AK, Sen B, Taneja N, Kundu M, Yamasaki S, and Ramamurthy T. 2008. Molecular characterization of multidrug-resistant Shigella species isolated from epidemic and endemic cases of shigellosis in India. J Med Microbiol. 57:856-63.

Penatti MP, Hollanda LM, Nakazato G, Campos TA, Lancellotti M, Angellini M, Brocchi M, Rocha MM, and Dias da Silveira W. 2007. Epidemiological characterization of resistance and PCR typing of Shigella flexneri and Shigella sonnei strains isolated from bacillary dysentery cases in Southeast Brazil. Braz J Med Biol Res. 40:249-58. 
$\mathrm{Pu}$ XY, Pan JC, Wang HQ, Zhang W, Huang ZC, and Gu YM. 2009. Characterization of fluoroquinolone-resistant Shigella flexneri in Hangzhou area of China. J Antimicrob Chemother. 63:917-20.

Ranjbar R, Hosseini MJ, Kaffashian AR, and Farshad S. 2010. An outbreak of shigellosis due to Shigella flexneri serotype 3a in a prison in Iran. Arch Iran Med. 13:413-6.

Recht MI, Douthwaite S, Dahlquist KD, and Puglisi JD. 1999. Effect of mutations in the A site of 16 S rRNA on aminoglycoside antibiotic-ribosome interaction. J Mol Biol. 286:33-43.

Ross JI, Eady EA, Cove JH, and Cunliffe WJ. 1998. 16S rRNA mutation associated with tetracycline resistance in a gram-positive bacterium. Antimicrob Agents Chemother. 42:1702-5.

Sack DA, Lyke C, McLaughlin C, Suwanvanichkij V, and World Health Organization. 2001. AntiInfective Drug Resistance Surveillance and Containment Team. Antimicrobial resistance in shigellosis, cholera and campylobacteriosis. WHO, Geneva, Switzerland. https://apps.who.int/iris/handle/10665/66875 (Last accessed February 2019).

Saeed A, Abd H, and Sandstrom G. 2015. Microbial aetiology of acute diarrhoea in children under five years of age in Khartoum, Sudan. J Med Microbiol. 64:432-7.

Sansonetti PJ. 2001. Shigellosis: from symptoms to molecular pathogenesis. Am J Physiol Gastrointest Liver Physiol. 280:G319-G323.

Sansonetti PJ., Kopecko DJ, and Formal SB. 1982. Involvement of a plasmid in the invasive ability of Shigella flexneri. Infect Immun. 35:852-60.

Shen H, Chen J, Xu Y, Lai Z, Zhang J, Yang H, Li Y, Jiang M, Ye Y, and Bai X. 2007. An outbreak of shigellosis in a Children Welfare Institute caused by a multiple-antibiotic-resistant strain of Shigella flexneri 2a. J Infect Public Health. 10:814-818.

Šimenc J, Golle A, and Potočnik U. 2008. Molecular identification of several clinically important bacteria including enterobacteria by partial $16 \mathrm{~S}$ ribosomal RNA gene sequence comparison. Zdravniški vestnik. 77:547-552.

Siu LK, Lo JY, Yuen KY, Chau PY, Ng MH, and Ho PL. 2000. beta-lactamases in Shigella flexneri isolates from Hong Kong and Shanghai and a novel OXA-1-like beta-lactamase, OXA-30. Antimicrob Agents Chemother. 44:2034-8.

Springer B, Kidan YG, Prammananan T, Ellrott K, Böttger EC, and Sander P. 2001. Mechanisms of streptomycin resistance: selection of mutations in the 16S rRNA gene conferring resistance.

Antimicrob Agents Chemother. 45:2877-84. 
Stafford R, Kirk M, Selvey C, Staines D, Smith H, Towner C, and Salter M. 2007. An outbreak of multi-resistant Shigella sonnei in Australia: possible link to the outbreak of shigellosis in Denmark associated with imported baby corn from Thailand. Euro Surveill. 12:E070913.1.

Suardana IW. 2014. Analysis of nucleotide sequences of the 16S rRNA gene of novel Escherichia coli strains isolated from feces of human and Bali cattle. J Nucleic Acids. 2014:475754.

Sun Q, Lan R, Wang J, Xia S, Wang Y, Wang Y, Jin D, Yu B, Knirel YA, and Xu J. 2013. Identification and characterization of a novel Shigella flexneri serotype Yv in China. PLoS ONE. 8:e70238.

Suzuki Y, Katsukawa C, Tamaru A, Abe C, Makino M, Mizuguchi Y, and Taniguchi H. 1998. Detection of kanamycin-resistant Mycobacterium tuberculosis by identifying mutations in the $16 \mathrm{~S}$ rRNA gene. J Clin Microbiol. 36:1220-1225.

Tamura K, and Nei M. 1993. Estimation of the number of nucleotide substitutions in the control region of mitochondrial DNA in humans and chimpanzees. Mol Biol Evol. 10:512-26.

Trieber CA, and Taylor DE. 2002. Mutations in the 16S rRNA genes of Helicobacter pylori mediate resistance to tetracycline. J Bacteriol. 184:2131-40.

Upton A, Mohiuddin J, Bathgate T, Taylor S, Simmons G, Woodhouse R, and Heffernan H. 2007. High prevalence of CTX-M-15 extended-spectrum beta-lactamase among contacts of patients with shigellosis due to Shigella flexneri carrying CTX-M-15. J Antimicrob Chemother. 60:906-8.

Vinh H, Nhu NT, Nga TV, Duy PT, Campbell JI, Hoang NV, Boni MF, My PV, Parry C, Nga TT, Van Minh P, Thuy CT, Diep TS, Phuong le T, Chinh MT, Loan HT, Tham NT, Lanh MN, Mong BL, Anh VT, Bay PV, Chau NV, Farrar J, and Baker S. 2009. A changing picture of shigellosis in southern Vietnam: shifting species dominance, antimicrobial susceptibility and clinical presentation. BMC Infect Dis. 9:204.

Walden VM, Lamond EA, and Field SA. 2005. Container contamination as a possible source of a diarrhoea outbreak in Abou Shouk camp, Darfur province, Sudan. Disasters. 29:213-21.

Woo PC, Lau SK, Teng JL, Tse H, and Yuen KY. 2008. Then and now: use of 16S rDNA gene sequencing for bacterial identification and discovery of novel bacteria in clinical microbiology laboratories. Clin Microbiol Infect. 14:908-34.

World Health Organization. 2004. Emergencies preparedness, response: Shigellosis in Sudan, available: https://www.who.int/csr/don/2004_07_14/en/ (Last accecesd February 2019).

World Health Organization. 2005. Guidelines for the control of shigellosis, including epidemics due to Shigella dysenteriae type 1: Geneva. 
bioRxiv preprint doi: https://doi.org/10.1101/2020.03.07.982017; this version posted March 8, 2020. The copyright holder for this preprint (which was not certified by peer review) is the author/funder, who has granted bioRxiv a license to display the preprint in perpetuity. It is made available under aCC-BY-ND 4.0 International license.

Yıldırım IHH, Yıldırım SC. And Koçak N. 2011. Molecular methods for bacterial genotyping and analyzed gene regions. Journal of Microbiology and Infectious Diseases. 1:42-46. 
bioRxiv preprint doi: https://doi.org/10.1101/2020.03.07.982017; this version posted March 8, 2020. The copyright holder for this preprint (which was not certified by peer review) is the author/funder, who has granted bioRxiv a license to display the preprint in perpetuity. It is made available under aCC-BY-ND 4.0 International license.

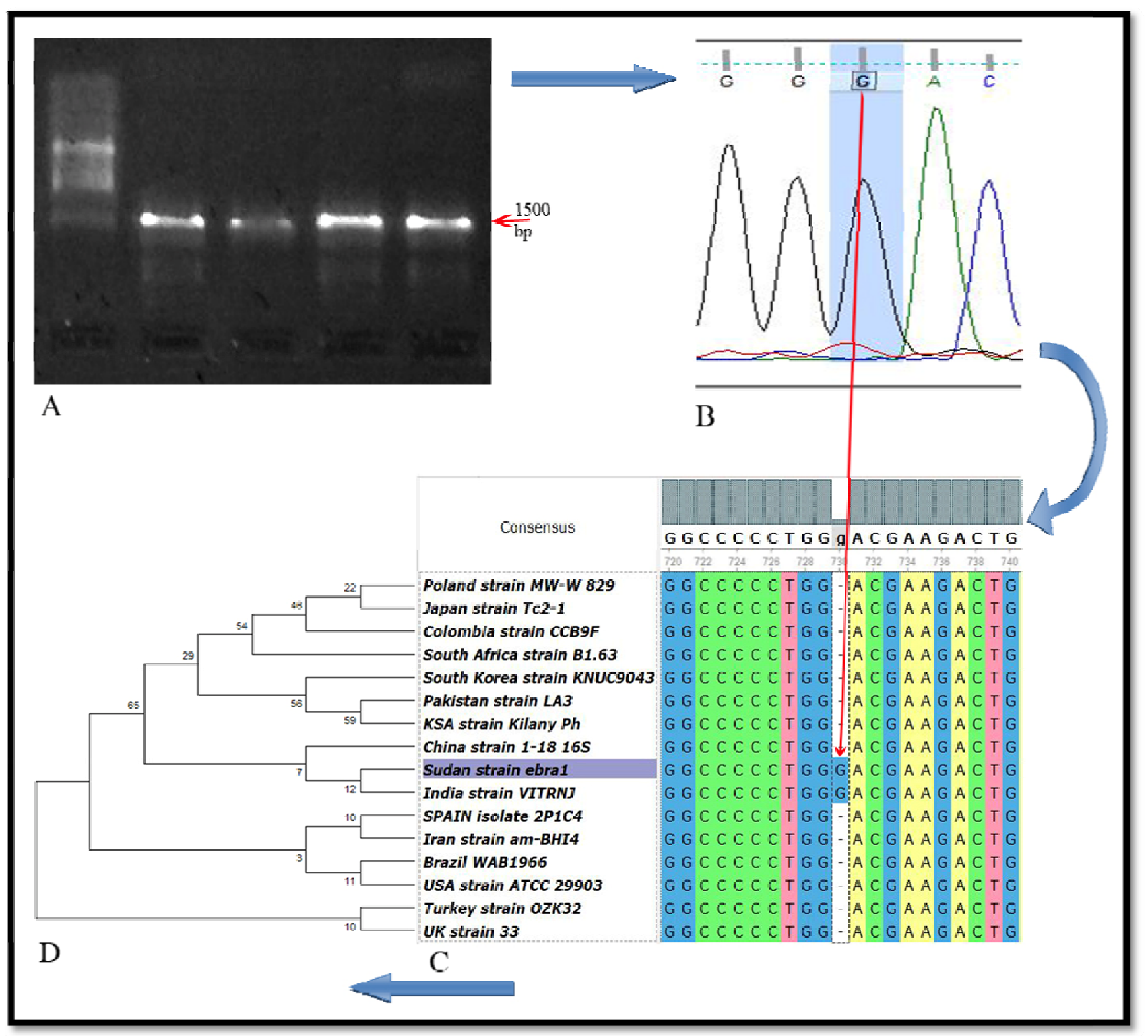

Figure 1: (A): PCR product of the S. flexneri's 16S rRNA gene run over \% agarose gel electrophoresis.

(B): 16S rRNA gene sequence chromatogram, shown by FinchTV software, indicating a guanine nucleotide insertion at position 730. (C): Alignment of ebral and JX307690.1 to other related sequences determining a guanine nucleotide insertion mutation using Unipro UGENE software version 1.25.0. (D):

Phylogenetic analysis of 16S rRNA gene sequences of Sudan strain, ebral, and selected strains of $S$. flexneri of other countries using MEGA software version 7. 